\title{
VIABILITY OF BIDDER REMEDIES UNDER SECTION 62 OF THE SOUTH AFRICAN MUNICIPAL SYSTEMS ACT
}

\author{
Kingsley Tochi Udeh
}

\section{(2016) 3:2 APPLJ 72}

\begin{abstract}
This article examines the extent to which an unsuccessful bidder is afforded a viable appeal remedy under section 62 of the Local Government: Municipal Systems Act No 32 of 2000, following the decision of the High Court in Loghdey $v$ City of Cape Town (100/09) [2010] ZAWCHC 25. Until this case held to the contrary, it was taken for granted that the section generally accorded unsuccessful bidders the right to internal appeal against the award decision of a municipality's delegated authority. Although a later decision of the Supreme Court of Appeal in CC Groenewald v M5 Developments (Pty) Ltd [2010] ZASCA 47 para 21, held that section 62 appeal is available to unsuccessful tenderers, it seemingly did not settle the issue; as it has been suggested that the two cases are distinguishable. Besides, consistent judicial interpretation of section $62(3)$ has further cast doubt on the viability of bidder remedies under the section.

It is argued here that the decision in Loghdey is flawed; and has been effectively overruled in CC Groenewald. Thus, section 62 definitely affords internal appeal rights to unsuccessful bidders against award decisions of municipalities' delegated authority. Furthermore, reasons are presented to urge the court to reconsider and depart from its current interpretation of section 62(3) that limits the viability of bidder remedy under section 62.
\end{abstract}




\section{VIABILITY OF BIDDER REMEDIES UNDER SECTION 62 OF THE SOUTH AFRICAN MUNICIPAL SYSTEMS ACT}

Kingsley Tochi Udeh

\section{LLB BL LLM LLD}

Research Associate, African Public Procurement Regulation Research Unit (APPRRU), Stellenbosch University, South Africa; Law Lecturer, Baze University Abuja, Nigeira; Consulting Partner, T.K Udeh \& Associates (Legal Practitioners \& Consultants).

\section{Introduction}

This article examines the extent to which an unsuccessful bidder is afforded a viable internal appeal remedy under section 62 of the Local Government: Municipal Systems Act No 32 of 2000 ("Systems Act"). In relation to public procurement, an internal appeal refers to a mechanism provided by law whereby aggrieved bidders could submit complaints regarding a procurement decision to the contracting authority for its reconsideration; before going or to avoid going to court or an external dispute resolution forum. Internal appeal has advantages over judicial review, ${ }^{1}$ which should ordinarily incline authorities, particularly the courts, towards sustaining the viability of the internal remedies under section 62 rather than defeating it.

Yet, certain decisions of South African courts have tended to undermine the viability of bidder remedies under section 62. These include: the High Court decision in Loghdey $v$ City of Cape Town; ${ }^{2}$ and the restrictive judicial interpretation given to section 62(3) of the Act. However, this paper argues that the decision in Loghdey is flawed; and has been effectively overruled by the SCA in CC CC Groenewald $v$ M5 Developments (Pty) Ltd. ${ }^{3}$ Furthermore, it presents reasons to urge the court to reconsider and depart from its current interpretation of section 62(3) that limits the viability of the internal remedy.

\footnotetext{
${ }^{1}$ As will be seen in 22 below.

2 (100/09) [2010] ZAWCHC 25.

3 [2010] ZASCA 47 para 21.
} 
The theme is topical considering that the appeal mechanism under section 62 , which applies exclusively to municipalities, is perhaps the only presumptively effective internal remedy under the South African procurement system. If its viability is firmly established it may lessen the "disturbing frequency" ${ }^{4}$ with which tender cases are coming before the courts.

\section{Significance of Municipal Procurement and Systems Act section 62}

\section{$21 \quad$ Municipal procurement and section 62}

South African municipal procurement is quite significant considering that all the 278 municipalities use procurement to provide infrastructure and services. ${ }^{5}$ A substantial number of the procurement cases that come to the courts are on municipal procurement. ${ }^{6}$ The frequency of these cases is not unconnected with the current paradigm on Systems Act section 62, as will be discussed below. ${ }^{7}$

Section 62 of the Systems Act established a well-structured internal review mechanism which all decisions by municipalities' delegated authority are subject to. It provides thus:

"A person whose rights are affected by a decision taken by a political structure, political office bearer, councillor or staff member of a municipality in terms of a power or duty delegated or sub-delegated by a delegating authority to the political structure, political office bearer, councillor or staff member, may appeal against that decision by giving written notice of the appeal and reasons to the municipal manager within 21 days of the date of the notification of the decision."

\footnotetext{
${ }^{4}$ As Nugent JA noted in South African Post Office v De Lacy 2009 (5) SA 255 (SCA) para 1. See Quinot 2011:198; and, Quinot 2013:313.

${ }^{5}$ See South African Government, 2016. See also Bolton 2007:3-4.

${ }^{6}$ See eg Jicama 17 (Pty) Ltd v West Coast District Municipality 2006 (1) SA 116 (C); Total Computer Services (Pty) Ltd v Municipal Manager, Potchefstroom Local Municipality 2008 (4) SA 346 (T); Syntell (Pty) Ltd v City of Cape Town [2008] ZAWCHC 120; Loghdey v Advanced Parking Solutions CC 2009 (5) SA 595 (C); M5 Developments (Cape) (Pty) Ltd v Groenewald NO [2009] JDR 0094 (C); Loghdey v City of Cape Town (100/09) [2010] ZAWCHC 25; Sanyathi Civil Engineering \& Construction (Pty) Ltd v eThekwini Municipality; Group Five Contruction (Pty) Ltd v eThekwini Municipality 2012 (1) BCLR 45 (KZP); Evaluations Enhanced Property Appraisals (Pty) Ltd v Buffalo City Metropolitan Municipality [2014] 3 All SA 560 (ECG); DDP Valuers (Pty) Ltd v Madibeng Local Municipality [2015] ZASCA 146; Aurecon South Africa (Pty) Ltd v City of Cape Town 2016 (2) SA 199 (SCA); Buffalo City Metropolitan Municipality $\checkmark$ Asla Construction (Pty) [2016] ZAECGHC 55.

7 Particularly below at 33 and 6 .
} 
It entitles "a person whose rights are affected by a decision" of a municipality's delegated authority to appeal to designated review bodies within the municipality. ${ }^{8}$ The affected person is required to commence the internal appeal by giving a written notice of appeal with reasons to the Municipal Manager, ${ }^{9}$ within 21 days following the notification of the decision being challenged. ${ }^{10}$ This commencement period cannot be extended. ${ }^{11}$ Time begins to run when the person had actual notice of the decision; not when he became aware of the irregularity of the action/decision. ${ }^{12}$ This aligns with public interest in the finality of administrative decisions and the exercise of administrative functions. The municipal manager must promptly submit the appeal to the appropriate review authority within the municipality. ${ }^{13}$ The appeal proceeding, in the case of procurement, involves: examining the objections raised; reviewing the tender process and documentation; obtaining opinions of officials that conducted the tender process; where necessary, seeking legal advice; and requesting written representations from the affected persons. ${ }^{14}$ Apart from the fact that the deadline for lodging the appeal is substantially shorter than the commencement timeframe for judicial review (180 days, with possibility of condonation/extension) $;{ }^{15}$ the appeal authority must commence hearing within six weeks of filing, and give its decision within a reasonable period. ${ }^{16}$ Prescribing the above timeframes facilitates the expeditious conclusion of the appeal proceedings.

The composition of the appeal authorities (forums) engenders independence and less likelihood of bias. First, each appeal forum within the municipality is a higher authority than the procurement decision-maker. Secondly, the forums are not composed of the

\footnotetext{
${ }^{8}$ Section 62(1), (2) \&(4). The scope of the locus standi is considered further under subheading 322 below.

${ }^{9}$ However, a tenderer's letter requesting information on the tender process, which discloses an intention to lodge an appeal, does not serve as a notice of appeal: Evaluations Enhanced Property Appraisals (Pty) Ltd v Buffalo City Metropolitan Municipality [2014] 3 All SA 560 paras 14 \& 50.

${ }^{10}$ Systems Act, s 62(1).

${ }^{11}$ Evaluations Enhanced Property Appraisals (Pty) Ltd v Buffalo City Metropolitan Municipality [2014] 3 All SA 560 para 73.

${ }^{12}$ Aurecon South Africa (Pty) Ltd v City of Cape 2016 (2) SA 199 (SCA) para 16.

${ }_{13}$ Systems Act, s 62(2).

${ }^{14}$ See CC Groenewald v M5 Developments [2010] ZASCA 47 paras 13-17.

${ }^{15}$ Promotion of Administrative Justice Act 3 of 2000 ("PAJA"), sections 7(1) and 9; rule 27 of Uniform Rules of Court; City of Cape Town v South African National Roads Agency Ltd 2015 (6) SA 535 (WCC) para 15.

${ }^{16} \mathrm{~S} 62(5)$.
} 
officers that took the challenged decision. The appeal authorities have powers to confirm, vary or revoke the appealed decision. ${ }^{17}$ However, they cannot refer the decision back to the decision-maker for reconsideration; ${ }^{18}$ and do not have power to suspend the affected procurement proceeding. Nevertheless, filing an appeal automatically suspends the proceeding, to prevent the entry into force of a contract. ${ }^{19}$ Decisions of the appeal authorities are binding; and their decisions will be readily followed, considering their status within the municipality.

\section{The significance}

Since it is an internal appeal mechanism, implementing the decision will be fast and simple. In general, the mechanism causes less disruption to procurement; and is cheaper than judicial review. As seen above, the appeal authority can vary or substitute the appealed decision, which presents more opportunity for correction of challenged decision than is generally available in judicial review. It is generally an important safeguard against faulty administrative decision-making. ${ }^{20}$

As hinted above, ${ }^{21}$ although the appeal under System Act section 62 is not the only internal review mechanism in South Africa applicable to procurement, it is the only one that constitutes an effective internal remedy. Thus, where any municipal decision is subject to section 62 appeal, it must be exhausted before recourse to judicial review, by virtue of section $7(2)(b)$ of PAJA. ${ }^{22}$ Regulation 49 of the Municipal Supply Chain

\footnotetext{
${ }^{17} \mathrm{~S} 62(3)$.

${ }^{18}$ CC Groenewald v M5 Developments [2010] ZASCA 47 para 27.

${ }^{19}$ Actaris South Africa (Pty) Ltd v Sol Platjie Municipality [2008] 4 All SA 168 (NC) para 27; Loghdey v City of Cape Town [2010] ZAWCHC 25 para 1; Chairperson, Standing Tender Committee v JFE Sapela Electronics [2005] 4 ALL SA 487 (SCA) paras 25 and 26. See also SCM Policy, City of Cape Town, S 245.

${ }^{20}$ Baxter 1984:255.

${ }^{21}$ Subheading 1.

${ }^{22}$ This enshrines the common law requirement on exhausting internal remedies. See Evaluations Enhanced Property Appraisals (Pty) Ltd v Buffalo City Metropolitan Municipality [2014] 3 All SA 560; Koyabe v Minister for Home Affairs 2009 (2) BCLR 1192 (CC) paras 35-40, 46-49; South African Municipal Workers Union v City of Cape Town [2005] ZAWCHC 39 para 163. Compare Compass Waste Services (Pty) Ltd v Chairperson Northern Cape Tender Board [2005] 4 All SA 425 (NC); Actaris South Africa (Pty) Ltd v Chairman of the Tender Committee [2007] ZAFSHC 136; Alexander Maintance and Electrical Services CC v Nyandeni Local Municipality [2012] ZAECMHC 10 (where judicial review was allowed notwithstanding that an internal remedy had not been exhausted; apparently because the party concerned did not object.
} 
Management Regulations ${ }^{23}$ also established an internal procurement review mechanism for municipalities; but is not an effective remedy option. First, regulation 49 only directs municipalities to make supply chain management policies that allow internal review of their procurement decisions. ${ }^{24}$ Thus, until the policy is made the internal review right remains inchoate. Secondly, its remedy is undefined. In DDP Valuers (Pty) Ltd $v$ Madibeng Local Municipality, ${ }^{25}$ it was held that regulation 49's review falls short of an internal remedy (requiring exhaustion) under section 7(2) of PAJA. Thirdly, the internal appeal under Systems Act section 62 obviates the usefulness of regulation 49; since both relate to municipalities' internal remedies, and being a statute, the application of Systems Act takes precedence over the Regulations (a subsidiary legislation). ${ }^{26}$

Notwithstanding its significance, the viability of bidder remedies under section 62 has unfortunately come under serious attack by certain judicial decisions, as hinted above, ${ }^{27}$ and critiqued immediately below.

\section{$3 \quad$ Loghdey's case and its aftermath}

\section{The case}

Until the High Court in Loghdey held to the contrary, unsuccessful tenderers in municipality procurement generally enjoyed a right of appeal under section 62 of the Systems Act. Syntell (Pty) Ltd $v$ City of Cape Town ${ }^{28}$ was one of such cases that upheld the right of unsuccessful bidders to appeal under section 62. I argue that the decision in Loghdey was erroneous, considering judicial precedent as at the time and other legal principles.

\footnotetext{
${ }^{23}$ GN 868 in GG 27636 of 30-5-2005, made in terms of section 168 of the Local Government: Municipal Finance Management Act No 56 of 2003.

${ }^{24}$ See Total Computer Services (Pty) Limited v Municipal Manager Potchefstroom Local Municipality 2008 (4) SA 346 (T) para 72; DDP Valuers (Pty) Ltd v Madibeng Local Municipality [2015] ZASCA 14616. ${ }^{25}$ [2015] ZASCA 14618 \& 20.

${ }^{26}$ For example, reg 49 stipulates 14 days for lodging a complaint, compared to 21 days under the Systems Act, s 62. However, the time under section 62 will prevail. See Quinot 2011:196-197.

${ }_{27}$ Subheading 1.

28 [2008] ZAWCHC 120.
} 
The brief facts of the case and its holding are presented first, followed by the critique.

Following a competitive bidding for the provision of a kerbside parking management service, the City of Cape Town awarded the tender contract to the successful bidder. Two unsuccessful bidders applied for the review and set-aside of the award. A ground of review was that the municipality, contrary to its Supply Chain Management Policy $(\mathrm{SCMP})^{29}$ and the condition of tender, did not notify all the bidders of its decision to accept the successful bid; and of their right, in terms of section 62 of the Systems Act, to appeal against the decision within 21 days of such notification, before the contract award. In response to this ground, the court raised an issue for determination, viz.: whether the unsuccessful bidders (applicants) had a right of appeal in terms of section 62 before the award $?^{30}$

The court ${ }^{31}$ answered the issue in the negative based on a number of assumptions which are highly contestable, as argued below.

\section{The contestable assumptions}

\section{Tender documents not binding and Syntell's case distinguishable}

The court, first, agreed with the decision in Loghdey $v$ Advanced Parking Solutions CC $^{32}$ that the City's SCMP did not in itself afford bidders a right of appeal under Systems Act section $62 .{ }^{33}$ Secondly, that there is a distinction between the case before it and Syntell (Pty) Ltd $v$ City of Cape Town, ${ }^{34}$ where the City had in the award notification expressly made its award subject to a right of appeal by the unsuccessful tenderers. ${ }^{35}$ The above opinions of the court partly led to its eventual refusal to accord unsuccessful bidders a right of appeal under section 62. It is thus relevant to assess the correctness of those opinions.

\footnotetext{
${ }^{29}$ Made pursuant to the Local Government: Municipal Finance Management Act 56 of 2003, s 111.

${ }^{30}$ Paras 23, 28.

${ }^{31}$ Paras 25, 28.

322009 (5) SA 595 (C).

${ }_{33}$ Para 25.

${ }^{34}$ [2008] ZAWCHC 120.

${ }^{35}$ Para 25.
} 
The first opinion above was based on the court's assumption that the clauses in the SCMP and the conditions of tender (in the tender invitation) that made the tender subject to the appeal under section 62 were merely an attempt by the City to record its understanding of the effect of section $62 .{ }^{36}$ Thus, that they are not binding; unlike an award notification that contained similar reference. This is contrary to the decision of the Constitutional Court in Allpay Consolidated Investment Holdings (Pty) Ltd $v$ Chief Executive Officer of the South African Social Security Agency NO, ${ }^{37}$ where it held that in procurement, the applicable legislation/policy and the tender documents constituted the legally binding and enforceable framework within which tenders had to be submitted, evaluated and awarded. ${ }^{38}$ Furthermore, that all the tender documentation and the tender in response thereto, read together, formed the basis for the formal contract to be concluded; and their requirements are not merely internal prescripts that contracting authorities may disregard at whim. ${ }^{39}$ This position of the Constitutional Court is preferable; and of course overrides the contrary opinion in Loghdey. The court in Loghdey would have accorded the SCMP and conditions of tender the same effect as the award notification, regarding their reference to the appeal under section 62. Moreover, section 1 of the Preferential Procurement Policy Framework Act 5 of 2000 defines an 'acceptable tender' as 'any tender which, in all respects, complies with the specifications and conditions of tender as set out in the tender document' ${ }^{4}$

On the court's second opinion above, it is noteworthy that Syntel/ was a High Court case which considered, as a substantive issue, the applicability of section 62 of the Systems Act in procurement matters. ${ }^{41}$ Thus, Loghdey and Syntell treated similar issue. Also, on the authority of Allpay seen above, tender documents and applicable policies have binding effect just as a letter of award notification. In fact, the court in Syntell stated that unsuccessful bidders' right to appeal under section 62 is not derived from a notification of

\footnotetext{
${ }^{36}$ Paras 25 (fn 18), 28, 31 (fn 21).

${ }^{37} 2014$ (1) BCLR 1 (CC) paras 38 \& 40. See Volmink 2014:45.

${ }^{38}$ See Chief Executive Officer of the South African Social Security Agency NO $v$ Cash Paymaster Services (Pty) Ltd 2012 (1) SA 216 (SCA) para 15.

${ }^{39}$ Paras 28, 40.

${ }^{40}$ Emphasis added.

${ }^{41}$ Para 2.
} 
award that referred to the section; rather, the "right already existed (ex lege) by virtue of section 62(1)". 42 On the whole, the two cases are not distinguishable, contrary to the court's position in Loghdey.

\section{Appeal right only for the person who has asked or applied for the decision}

The court in Loghdey ${ }^{43}$ misconstrued and applied strictly the rule in Reader $v$ Ikin ${ }^{44}$ as upheld in Municipality of the City of Cape Town v Reader, ${ }^{45}$ that section 62 appeal is only for the person who has asked or applied for the decision, as if the case before it is on all fours with Reader case. Actually the facts and issues canvassed in Reader are not similar to those in Loghdey. The issue in Reader was whether third parties, who objected to a grant of planning permission to an applicant, had right of appeal under section 62 of the Systems Act, which must be exhausted before judicial review. The objectors had instituted review proceedings to set aside the municipality's approval of a certain individual's building plan. They lived within the neighbourhood where the building will be constructed. The municipality opposed the review application on the ground that the objectors failed to exhaust the appeal under section 62 , before recourse to court, contrary to section 7(2) of PAJA. The Full Court held that section 62 provides an internal remedy contemplated in section 7(2) of PAJA for a party aggrieved by the initial decision; but does not extend to third parties who contend that their rights or legitimate expectations have been adversely affected by the decision. ${ }^{46}$ This agreeable decision, on appeal, was supported by the SCA, which further held that the objectors have not alleged that the approval itself affected their rights (as provided by Systems Act section 62); but only that the execution of the approval (the construction) affected their rights. ${ }^{47}$

The Reader cases are thus distinguishable from Loghdey. Loghdey (an unsuccessful bidder) was most certainly a party to the procurement proceeding and the resultant

\footnotetext{
42 Paras 65, 68.

${ }^{43}$ Paras 30, 33.

${ }^{44} 2008$ (2) SA 582 (C).

${ }^{45} 2009$ (1) SA 555 (SCA). This is Reader v Ikin 2008 (2) SA 582 (C) on appeal.

${ }^{46}$ Reader v Ikin 2008 (2) SA 582 (C) para 32; Municipality of the City of Cape Town v Reader 2009 (1) SA 555 (SCA) para 12.

${ }^{47}$ Municipality of the City of Cape Town v Reader 2009 (1) SA 555 (SCA) para 17
} 
decision; ${ }^{48}$ unlike the objectors in Reader, who were third parties to the permit application. The issue in Reader was on application of section 62 to third party objection against approval of permit; while in Loghdey, the issue was application of section 62 to unsuccessful bidders that participated in the disputed procurement process. If the court in Loghdey had rightly distinguished the cases, it would have held that unsuccessful bidders have right to appeal under section 62. This was exactly what the court in Syntell did, and held that "Syntell (an unsuccessful bidder) is clearly a party whose rights are affected by the tender award"; 49 thus, that he has a right of appeal under section $62 .{ }^{50}$

\section{Precedents overruled}

It is apparent that the court in Loghdey ${ }^{51}$ assumed that the SCA's upholding of Reader case, being a decision of a superior court, overruled the earlier High Court decisions ${ }^{52}$ that held that unsuccessful bidders enjoyed appeal right under section 62. As seen above, Reader cases were not on procurement challenge by bidders; but on third parties' objection against a planning permit approval. Thus, those precedents were distinguishable from Reader Cases and hence not overruled. The court in Loghdey should have followed those precedents.

Also, in Loghdey, ${ }^{53}$ the court, relying on Reader, opined that there was no 'viable' appeal remedy available under section 62(1) of the Systems Act by virtue of the limiting effect of section 62(3). ${ }^{54}$ However, earlier High Court cases have held that section 62(3) renders the remedies under the section ineffective only against a right that has accrued from the appealed decision. ${ }^{55}$ These cases do not support the sweeping derogation of

\footnotetext{
${ }^{48}$ See Quinot 2011:196.

49 Para 30 (emphasis added).

${ }^{50}$ Paras 60, 62 and 65; 82-83.

${ }^{51}$ Fn 19.

${ }^{52}$ Such as Jicama 17 (Pty) Ltd v West Coast District Municipality 2006 (1) SA 116 (C); Total Computer Services (Pty) Ltd v Municipal Manager, Potchefstroom Local Municipality 2008 (4) SA 346 (T); Syntell (Pty) Ltd v City of Cape Town [2008] ZAWCHC 120; Loghdey v Advanced Parking Solutions CC 2009 (5) SA 595 (C).

${ }^{53}$ Para 34, see fn 23.

${ }^{54}$ The subsection is presented and analysed below, subheading 5.

55 Syntell (Pty) Ltd v City of Cape Town [2008] ZAWCHC 120 paras 60, 65; Loghdey v Advanced Parking Solutions CC 2009 (5) SA 595 (C) paras 28, 25-27; Lohan Civil-Tebogo Joint Venture v Mangaung Plaaslike Munisipaliteit 508/2009 (O) [2009] ZAFSHC 21 para 28.
} 
unsuccessful tenderers' right of appeal under section 62, as held in Loghdey. The aforementioned position in the earlier cases was not overruled by Reader as assumed in Loghdey. Rather, Reader held that the combined interpretation of section 62(1) and (3) did not provide any viable remedy to "third parties who contend that their rights or legitimate expectations have been adversely affected by the decision"; 56 not unsuccessful bidders, who are certainly parties to the challenged procurement proceeding/decision.

\section{The aftermath}

The decision in Reader had caused unwarranted confusion as to the applicability of section 62 to procurement. For example, in the event leading to the Loghdey case, the municipality had at an occasion informed the unsuccessful bidder that appealed under section 62 that it no longer had such right; later, it agreed to continue with the proceeding. ${ }^{57}$ However, Syntell, by distinguishing Reader and holding that its ratio does not extend to procurement, virtually restored the status quo ante on section 62 . But the decision in Loghdey reversed this gain, and threatened the viability of section 62 as an internal remedy for procurement.

This situation, as observed by the court in Syntell, 58 "would result, one would imagine, in an increase in the number of reviews brought before court, a process which is more expensive, time consuming and require a more onerous burden to discharge than does an internal appeal."

However, two months after the decision in Loghdey, the SCA came to the rescue through its decision in CC Groenewald v M5 Developments (Pty) Ltd ${ }^{59}$ discussed below.

\footnotetext{
${ }_{56}$ Paras 11, 36.

${ }^{57}$ Para 61. See also Syntell (Pty) Ltd v City of Cape Town [2008] ZAWCHC 120 paras 18-23.

${ }_{58}^{5}$ Para 35.

${ }^{59}$ [2010] ZASCA 47.
} 


\section{$4 \quad$ CC Groenewald case and its significance}

\section{The case}

The municipality of Cape Town had invited tenders for the construction of low cost houses. Following the conclusion of the procurement process, the successful bidder (M5) was informed that its tender was successful, and the unsuccessful bidders were simultaneously informed in writing of the outcome and that they had 21 days to lodge a section 62 appeal. Two unsuccessful bidders (Blue Whale and ASLA) appealed- Blue Whale within appeal time, ASLA out of time. The appeal authority reversed the award made to M5 and awarded it to ASLA. M5 filed a judicial review application at the High Court, which was upheld. On appeal to the SCA, the first issue was whether an appeal against the award of the contract lay under section 62(1) of the Systems Act. The SCA reviewed the decision in Reader; and opined that Reader did not address whether an unsuccessful tenderer has a right to appeal against the acceptance of the tender of another. ${ }^{60}$ It further distinguished the case before it from Reader; and held that unsuccessful bidders enjoy a right of appeal under section $62,{ }^{61}$ thus:

"In the present case, of course, the unsuccessful tenderers, together with M5, were all parties to the tender approval process. I therefore have no difficulty in concluding that both ASLA and Blue Whale were entitled to appeal under s 62."

The SCA also laid a further relevant precedent: that an appeal authority neither has the power to reconsider all the tenders submitted (but only successful tender and tenders of those that appealed) nor award to a bidder that did not appeal. ${ }^{62}$ This is intended to forestall "administrative anarchy" and to speed up the appeal process. ${ }^{63}$ It enhances the viability of bidder remedies under section 62 .

\footnotetext{
${ }^{60}$ Para 19.

${ }^{61}$ Paras 20-21

62 Paras 22-25.

${ }_{63}$ Para 23.
} 


\section{Whether distinguishable from Loghdey?}

The above decision ordinarily settles the issue of the right of bidders to appeal under section 62. Nonetheless, it has been suggested that Loghdey may be distinguishable from CC Groenewald, since in the latter it was stated in the notification of the award that it was subject to the 21-day appeal period under section 62 and that a contract would be concluded after that period had lapsed; whereas, in the former the award notification did not contain such condition. ${ }^{64}$ If $C C$ Groenewald and Loghdey are actually distinguishable it means the decision in Loghdey would be treated as still subsisting.

However, a supportable view is that the two cases are not distinguishable in that regard. First, the SCA in CC Groenewald did not regard the reference to section 62 in the award notification as what entitled an unsuccessful tenderer to appeal. It is clear that the court regarded that the right accrued to unsuccessful bidders by law (ex lege) and not by contract (ex contractu). ${ }^{65}$ Secondly, in Loghdey, a condition similar to the aforementioned one in CC Groenewald was contained in the municipality's SCMP and in the conditions of tender. ${ }^{66}$ The SCMP and the conditions of tender are deemed incorporated into the award notification and binding on all the parties, as held by the Constitutional Court in Allpay, discussed above. ${ }^{67}$ Thirdly, in Loghdey, the court regarded such condition as merely informative and immaterial in determining whether a right of appeal existed, thus:

"To attach to such decision (award) a note that it is subject to appeal is not to derogate from its finality." ${ }^{.68}$

This is also evident in its statement that: "The City's noncompliance with those clauses (conditions) can therefore be material only if APS (unsuccessful bidder) enjoyed a right of appeal in terms of $s, 62$ by reason of the provisions of that section read on its own." 69

\footnotetext{
${ }^{64}$ See Quinot 2011:197.

${ }^{65}$ See also Syntell para 41.

${ }^{66}$ See Loghdey $v$ City of Cape Town [2010] ZAWCHC 25 paras 16, 18 (fn 15), 23, 28, 32.

${ }^{67}$ See 321.

${ }^{68}$ Para 32; see also paras 29-31. Notwithstanding, it had accepted the distinction made by the court of first instance between Lodhgey and Syntell (Pty) Ltd $v$ City of Cape Town [2008] ZAWCHC 120 on the issue of making an award subject to appeal period in the award notification.

${ }^{69}$ Para 29 (emphasis added).
} 
Of course it held that the section does not apply to unsuccessful bidders. ${ }^{70}$ Fourthly, the SCA in CC Groenewald ${ }^{71}$ categorically held that the ratio in Reader does not apply to unsuccessful bidders- the decision in Loghdey was squarely based on the ratio in Reader.

Thus, an unsuccessful bidder's appeal right under section 62 does not depend on whether the award notification makes the award subject to section $62 .{ }^{72}$

\section{Its significance}

It should be regarded as settled that CC Groenewald has overruled the decision in Loghdey concerning an unsuccessful bidder's appeal right under section 62. First, CC Groenewald is the decision of the SCA, which is superior to the HC that decided Loghdey, and can overrule Loghdey. Secondly, CC Groenewald dealt directly with the issue of right of unsuccessful tenderers to the internal appeal under section 62. It also clearly distinguished the decision in Reader (which was the basis of the decision in Loghdey) from the case before it; and rendered its ratio decidendi in Reader inapplicable to bidder remedies. Thirdly, the SCA's decision in CC Groenewald prevails over that of the $\mathrm{HC}$ in Loghdey to the extent of its inconsistency, based on the doctrine of judicial precedent.

Thus, CC Groenewald fully restored the right of unsuccessful bidders to appeal under section 62. This position was followed and strengthened in more recent cases, such as Evaluations Enhanced Property Appraisals (Pty) Ltd $v$ Buffalo City Metropolitan Municipality, ${ }^{73}$ and DDP Valuers (Pty) Ltd $v$ Madibeng Local Municipality. ${ }^{74}$ In DDP Valuers case ${ }^{75}$ the SCA regarded, as a matter of course, that a municipality's unsuccessful tenderer enjoys the right of internal appeal under section 62; and moreover, is obligated to exhaust that appeal before resorting to judicial review. ${ }^{76}$

\footnotetext{
70 Paras 33, 35.

${ }^{71}$ Paras 30, 33, 34 (fn 23).

72 Supported by Quinot 2011:197.

${ }^{73}$ [2014] 3 All SA 560 (ECG) paras 72, 73, 79(3)(2).

${ }^{74}$ [2015] ZASCA 146.

75 Paras 23-25.

${ }^{76}$ Pursuant to PAJA, s 7(2).
} 
Notwithstanding that $C C$ Groenewald and subsequent cases have restored the right of unsuccessful bidders to appeal under section 62 Systems Act, the assault on the viability of this internal remedy is not over yet. For it still contends with the current unduly limiting judicial interpretation of section 62(3), as discussed immediately below.

\section{$5 \quad$ Effect of section 62(3) on the appeal remedies}

\section{The subsection and its current interpretation}

Section 62(3) states that:

"The appeal authority must consider the appeal, and confirm, vary or revoke the decision, but no such variation or revocation of a decision may detract from any rights that may have accrued as a result of the decision."

The subsection indicates the remedies that an appeal authority may exercise in resolving the dispute. These remedies are far-reaching and effective for redressing breaches in procurement processes. ${ }^{77}$

However, South African courts ${ }^{78}$ have interpreted the subsection to mean that section 62 appeal cannot succeed if it will result in a revocation or variation of a right that has accrued from the decision in issue. This effectively exempts unconditional award or concluded contracts from the appeal. ${ }^{79}$ However, where an award is made subject to the appeal period, the right cannot accrue until the lapse of that time.$^{80}$ Furthermore, if the appeal is commenced within the stipulated period, the accrual of right remains suspended until the completion of the appeal proceedings. ${ }^{81}$

Stipulating in the policy or tender/notification documents that award would be subject to the appeal period safeguards the viability of the bidder remedies under section 62 .

\footnotetext{
77 See 22 above.

78 See Loghdey v City of Cape Town [2010] ZAWCHC 25 para 33; Loghdey v Advanced Parking Solutions CC 2009 (5) SA 595 (C); Lohan Civil-Tebogo Joint Venture v Mangaung Plaaslike Munisipaliteit 508/2009 (O) [2009] ZAFSHC 21. See also City of Cape Town v Reader 2009 (1) SA 555 (SCA) paras $25,31$.

${ }^{79}$ See Quinot, 2011:197.

${ }^{80}$ Syntell (Pty) Ltd v City of Cape Town [2008] ZAWCHC 120 paras 59-60.

${ }^{81}$ Paras 59-60.
} 
However, the practice does not completely eliminate the threat posed by the restrictive interpretation of the subsection. The argument presented immediately below for a reconsideration of the current interpretation of the subsection is thus worthwhile.

\section{$52 \quad$ Need for review}

Notwithstanding that the above judicial interpretation appears settled; the following are reasons to reconsider it.

First, subsection 3 should not be read in isolation, but in the context of other provisions of section 62.82 The primary purpose of the section is to provide remedies; which include confirming, varying or revoking the challenged decision. Thus, the aforementioned interpretation undermines the essence of section $62 ; 83$ which arguably cannot be the intention of the legislature- for the purpose of a law ought to be given effect rather than being defeated. ${ }^{84}$ As said by Blackstone: "One part of the statute must be so construed by another that the whole may, if possible, stand." 85

Secondly, the interpretation ignores that the word may, which qualifies the notion of not detracting from an accrued right, should be regarded as connoting a permissive not mandatory requirement. ${ }^{6}$ It is significant that while "may" was used in the foregoing, the same subsection used "must", which is indicative of a mandatory requirement, ${ }^{87}$ to qualify the consideration of the appeal.

Thus, section 62(3) should be interpreted to mean that where a right has accrued from a decision, the appeal authority has discretion to decide whether the decision should be left

\footnotetext{
${ }^{82}$ See South African Police Service v Police and Prisons Civil Rights Union 2011 (6) SA 1 (CC) para 30; Botha v Rich NO 2014 (4) SA 124 (CC) para 35.

${ }^{83}$ This was acknowledged in Loghdey $v$ City of Cape Town [2010] ZAWCHC 25 paras 32-33. See Quinot 2011:197.

${ }^{84}$ Ut res magis valeat quam pereat. See Rex v Cotterill (1817) 1 B \& Ald 81; The Beta (1865) 3 Moo PCC NS 23 25; and Bennion 1990:117-118.

${ }^{85}$ Blackstone 1765:i 64.

${ }^{86}$ See Botha v Rich NO 2014 (4) SA 124 (CC) para 35; South African Police Service v Public Servants Association 2007 (3) SA 521 (CC). It is however acknowledged that, in appropriate circumstances, courts construe the word "may" as mandatory: see Wade \& Forsyth 2000:239.

${ }^{87}$ See Botha $v$ Rich NO 2014 (4) SA 124 (CC) para 35. See also Kim 2008:9.
} 
undisturbed or be varied or revoked. ${ }^{88}$ For example, where contract performance has commenced or is virtually completed, the award decision may not be varied or revoked, considering the hardship that may be caused to the contractor. ${ }^{89}$ However, where the contract has merely been awarded, decision may be appealable. ${ }^{90}$ This accords with what obtains generally in judicial review.

\section{Conclusion}

The internal appeal under section 62 of Systems Act should be considered in a manner that sustains its general viability as a bidder remedies mechanism. This is not only because of its advantages as an internal remedy, but also because relevant legal principles discussed above support such approach.

It should be regarded that $C C$ Groenewald has fully overridden Loghdey; thus, the current position is that unsuccessful tenderers enjoy a right of internal appeal under section 62 of Systems Act. Also, that it constitutes a viable internal remedy which aggrieved bidders are obligated to exhaust before resorting to judicial review, ${ }^{91}$ by virtue of $D D P$ Valuers (Pty) Ltd $v$ Madibeng Local Municipality.92 Notwithstanding that the restrictive interpretation give to section 62(3) appears settled, South African courts should reconsider its current position, as suggested above, so as to give effect to the law rather than making it fail.

In the meantime, the practice by many municipalities of providing in the policy or tender/notification documents that award would be subject to section 62 appeal period, which safeguards the viability of the appeal, should be sustained. It is in the municipalities'

\footnotetext{
${ }^{88}$ The municipalities had been exercising this discretion, as the court in Loghdey $v$ City of Cape Town [2010] ZAWCHC 25 para 34 acknowledged, but disallowed.

${ }^{89}$ Chairperson, Standing Tender committee $v$ JFE Sapela Electronics [2005] 4 ALL SA 487 (SCA) paras

27-29; Sebeza Kahle Trade v Emalahleni Local Municipal Council [2003] 2 ALL SA 340 (T) 348.

${ }^{90}$ Note the argument of counsel in Reader $v$ Ikin 2008 (2) SA 582 (C) (also referred to in Syntell (Pty) Ltd $v$ City of Cape Town para 55), which the court rejected, that "accrued" fell to be construed in a manner that denoted a right that had not only been acquired, but also acted upon. Both Mohamed NO v Union Government (Minister of Interior) 1911 AD 1 10, and Abbott $v$ The Minister for Lands [1895] AC 425 (PC), support this argument.

${ }^{91}$ Pursuant to PAJA, s 7(2).

${ }^{92}$ [2015] ZASCA 146 paras 23-25.
} 
interest, as well as that of all tenderers, and indeed of the public at large, that there is an internal appeal mechanism available in procurement matters. It affords an opportunity for resolution of procurement disputes cheaply and speedily; with less likelihood of resorting to court and increasing its burden, ${ }^{93}$ while avoiding its attendant disruption of the procurement process.

On the whole, it is advised that aggrieved bidders in a municipality's procurement process should first file a section 62 appeal, before proceeding to judicial review- if the appeal is refused or they are unsatisfied with the outcome.

\footnotetext{
${ }^{93}$ The SCA in CC Groenewald v M5 Developments [2010] ZASCA 47 para 1 expressed its concern thus: "As this court has recently observed, awards of tenders in the public sector are a fruitful source of litigation which has led to courts being swamped with cases concerning complaints about the award of contracts." See also Moseme Road Construction CC \& others v King Civil Engineering Contractors (Pty) Ltd [2010] ZASCA 13 para 1.
} 


\section{Bibliography}

Baxter, L. 1984. Administrative Law. Cape Town: Juta.

Bennion, F. 1990. Bennion on Statute Law. London: Longman.

Blackstone, W. 1765. Commentaries on the Laws of England. Oxford: Clarendon Press.

Bolton, P. 2007. The Law of Government Procurement in South Africa. Durban: LexisNexis.

Kim, Y. 2008. Statutory Interpretation: General Principles and Recent Trends. Washington: Congressional Research Service.

Quinot, G. 2011. Enforcement of Procurement Law from a South African Perspective. Public Procurement Law Review 20:193-206.

Quinot, G. 2013. A Comparative Perspective on Supplier Remedies in African Public Procurement Systems. In Quinot, G. \& Arrowsmith, S. (Eds.). Public Procurement Regulation in Africa. Cambridge: Cambridge University Press.

Volmink, P. 2014. Legal Consequences of Non Compliance with Bid Requirements. Afrcan Public Procurement Law Journal 1:41-60.

Wade, HWR. \& Forsyth, CE. 2014. Administrative Law. 11 ed. Oxford: Oxford University Press.

$\underline{\text { Jurisprudence }}$

Abbott $v$ The Minister for Lands [1895] AC 425 (PC).

Actaris South Africa (Pty) Ltd v Chairman of the Tender Committee [2007] ZAFSHC 136.

Actaris South Africa (Pty) Ltd v Sol Platjie Municipality [2008] 4 All SA 168 (NC). 
Alexander Maintance and Electrical Services CC v Nyandeni Local Municipality [2012] ZAECMHC 10.

Allpay Consolidated Investment Holdings (Pty) Ltd $v$ Chief Executive Officer of the South African Social Security Agency NO 2014 (1) BCLR 1 (CC).

Aurecon South Africa (Pty) Ltd v City of Cape 2016 (2) SA 199 (SCA).

Botha v Rich NO [2014] ZACC 11, 2014 (4) SA 124 (CC).

Buffalo City Metropolitan Municipality v Asla Construction (Pty) [2016] ZAECGHC 55. CC Groenewald v M5 Developments (Pty) Ltd [2010] ZASCA 47.

Chairperson, Standing Tender committee v JFE Sapela Electronics [2005] 4 ALL SA 487 (SCA).

Chief Executive Officer of the South African Social Security Agency NO $v$ Cash Paymaster Services (Pty) Ltd 2012 (1) SA 216 (SCA).

City of Cape Town v South African National Roads Agency Ltd 2015 (6) SA 535 (WCC).

Compass Waste Services (Pty) Ltd v Chairperson Northern Cape Tender Board [2005] 4 All SA 425 (NC).

DDP Valuers (Pty) Ltd v Madibeng Local Municipality [2015] ZASCA 146.

Evaluations Enhanced Property Appraisals (Pty) Ltd v Buffalo City Metropolitan Municipality [2014] 3 All SA 560 (ECG).

Jicama 17 (Pty) Ltd v West Coast District Municipality 2006 (1) SA 116 (C).

Koyabe v Minister for Home Affairs 2009 (2) BCLR 1192 (CC).

Loghdey v Advanced Parking Solutions CC 2009 (5) SA 595 (C).

Loghdey v City of Cape Town [2010] ZAWCHC 25. 
Lohan Civil-Tebogo Joint Venture v Mangaung Plaaslike Munisipaliteit 508/2009 (O) [2009] ZAFSHC 21.

M5 Developments (Cape) (Pty) Ltd v Groenewald NO [2009] JDR 0094 (C).

Mohamed NO v Union Government (Minister of Interior) 1911 AD 110.

Moseme Road Construction CC \& others v King Civil Engineering Contractors (Pty) Ltd [2010] ZASCA 13.

Municipality of the City of Cape Town v Reader 2009 (1) SA 555 (SCA).

Reader v Ikin 2008 (2) SA 582 (C).

Rex v Cotterill (1817) 1 B \& Ald 81.

Sanyathi Civil Engineering \& Construction (Pty) Ltd v eThekwini Municipality, Group Five Contruction (Pty) Ltd v eThekwini Municipality 2012 (1) BCLR 45 (KZP).

Sebeza Kahle Trade v Emalahleni Local Municipal Council [2003] 2 ALL SA 340 (T) 348.

South African Municipal Workers Union v City of Cape Town [2005] ZAWCHC 39.

South African Police Service v Police and Prisons Civil Rights Union 2011 (6) SA 1 (CC).

South African Police Service v Public Servants Association 2007 (3) SA 521 (CC).

South African Post Office v De Lacy 2009 (5) SA 255 (SCA).

Syntell (Pty) Ltd v City of Cape Town [2008] ZAWCHC 120.

The Beta (1865) 3 Moo PCC NS 2325.

Total Computer Services (Pty) Ltd $v$ Municipal Manager, Potchefstroom Local Municipality 2008 (4) SA 346 (T). 


\section{Legislation (South Africa)}

Local Government: Municipal Finance Management Act 56 of 2003.

Local Government: Municipal Systems Act 32 of 2000.

Municipal Supply Chain Management Regulations, GN 868 in GG27636 of 30-5-2005.

Promotion of Administrative Justice Act 3 of 2000.

Supply Chain Management Policy 2013 (City of Cape Town).

Uniform Rules of Court, 2009, made in terms of the Supreme Court Act 59 of 1959.

\section{$\underline{\text { Internet sources }}$}

South African Government, 2016. Local Government. South African Government, [online]. Available at: <https://www.gov.za/about-government/governmentsystem/local-government> [Accessed 02-11-2016]. 